University of Nebraska - Lincoln

DigitalCommons@University of Nebraska - Lincoln

July 2021

\title{
Curbside book pick-up services during a time of crisis in South African University Libraries
}

Dina Mashiyane

University of the Free State, mashiyanedm@ufs.ac.za

Mahlaga Molepo

University of the Free State, MolepoMJ@ufs.ac.za

Follow this and additional works at: https://digitalcommons.unl.edu/libphilprac

Part of the Library and Information Science Commons

Mashiyane, Dina and Molepo, Mahlaga, "Curbside book pick-up services during a time of crisis in South African University Libraries" (2021). Library Philosophy and Practice (e-journal). 5808.

https://digitalcommons.unl.edu/libphilprac/5808 


\title{
Curbside book pick-up services during a time of crisis in South African University libraries.
}

\begin{abstract}
Purpose

This paper sought to determine the implementation of curbside pick-up services within South African University libraries during the Covid-19 pandemic.

\section{Design/methodology/approach}

The study employed a quantitative approach where informetrics has been used as the primary data collection method to analyse the implementation of curbside/book pick-up services on the web pages of 26 South African University Libraries.

\section{Findings}

This study indicates that only a few South African university libraries have implemented curbside pick-up services. The study further reveals that those libraries that have implemented this type of service have utilised various methods to facilitate book requests.

\section{Practical implications}

This study recommends the development of contingency plans for libraries to stay abreast of changes in their environments. The implementation of enhanced and innovative lending services for printed materials.

\section{Social implications}

The paper sheds light on a strategic method for enhancing lending services in academic libraries. It can also be used as a benchmarking tool for those libraries planning on implementing this type of service. The usage of curbside pick-up services can be essential during times of crisis in enhancing lending endeavors and meeting the needs of the users

\section{Originality/value}

This study adds value to the innovative lending services in libraries, especially during times of crisis. As there is no evidence of previously conducted studies on this phenomenon, this paper can be used to initiate further research on curbside book pick-up services in libraries

Keywords: Curbside pick-up services, Academic libraries, print collections, Covid-19; lending services. 


\section{Introduction}

Information dissemination is one of the anchoring services provided by libraries. Libraries pride themselves in providing access to collections in various formats to meet the changing needs of their users. The emergence of a health pandemic with the ability to force the world to come to a standstill has influenced the embracement of Information and Communication Technologies (ICT's) by various professions. Libraries are no exceptions, as they try and source new ways in reaching out and serving their patrons beyond the library walls. Covid-19 or CoronaVirus has seen many universities closing their doors and opting for Emergency Remote Teaching (ERT) as a solution to complete the 2020 academic year. China's educational system has launched the ERT intervention as a contingency plan with a mission of "suspending schools without stopping teaching-learning" (Zhang, 2020). The closure and limited access to libraries have left users deserted, especially in accessing printed materials from the library. Most academic libraries expanded their book budgets to accommodate the acquisition of eBooks to support ERT. However, the challenge remained with books that are only available in print formats. Most academic libraries throughout the world have implemented curbside pick-up services where users can request print books through various channels with scheduled collections or pick-ups (Campbell et al., 2020; Farrell, 2020; Gibson et al., 2020; Harris, 2020).

The paper explores the implementation of curbside pick-up services by university libraries in South Africa as a means for enhancing book lending endeavors during a time of crisis. It is motivated by applying a service that has been historically dominant and embedded in retail and fast food industries within the library landscape. There is scant research done globally on the phenomenon. The study will shed light on curbside pick-up services that libraries can implement to facilitate information dissemination during times of crisis. It can also motivate libraries to embed curbside pick-ups as an additional service after this pandemic. The study can also be used to initiate further research in this area.

\section{Objectives of the study}

- To identify South African universities which have implemented curbside pick-up services during Covid-19.

- To explore the book requisition method being used by each library.

- To make recommendations for further research

\section{Background}

South Africa has a total of 26 universities. Each university has an academic library that supports their teaching, learning and research activities. Traditionally, academic libraries disseminate information by allowing users to visit the library to collect printed library resources physically. Since the announcement of a national lockdown due to the COVID 19 pandemic, the traditional information dissemination method has been severely disrupted. For instance, library users were neither allowed to enter campus nor visit academic libraries during national lockdown level 5. Prohibitions of movement and travel differed according to the lockdown levels and are reviewed by the National Corona Virus Command Council (NCCC). South Africa embarked on a national lockdown on March 27 2020, as a contingency plan to curb the spread of the virus. 
The phased-in return to campuses by various students based on their levels of the study prompted the need to access electronic resources and books available in print format. Academic members had to rely on printed copies of those not available electronically to continue teaching and learning practices. Dramatic Artistic and Literary Rights Organization (DALRO) and Publishers Association of South Africa(PASA) issued out a memorandum in which they provided their assistance to South African universities in a effort to enhance access to educational resources (UP, 2020). According to Phalad (2020), this mandated publishers to assist university libraries in making available additional electronic resources to their users during COVID-19. Printed books were digitised under strict regulations. Librarians needed to check whether the books were available in electronic format through various vendors before scanning or digitizing requested chapters. The standard limitation of $10 \%$ or one chapter sufficed. Copyright Application Forms were completed in instances where there was a need for additional chapters within a single title. Copyright regulations during the pandemic have affected most libraries worldwide, not only in South Africa (Ma, 2020; Tammaro, 2020). Academic libraries had to liaise with publishers in enhancing access to electronic resources. An example of such an initiative was reported by PASA (2021) where University of the Witwatersrand (WITS) collaborated with publishers in providing free content to students and researchers. This agreement between WITS and publishers allowed students and researchers to have unrestricted access to a collection of eBooks.

To ensure that users do not incur any fines for books already on loan, libraries extended the loan periods and used book drop boxes for users who could access the university's vicinity. Results from the survey conducted by the Committee of Higher Education Libraries of South Africa (CHELSA, 2021), which was distributed to a total of 29 institutions comprising of 26 university libraries, the National Library of South Africa, the Council for Scientific and Industrial Research (CSIR) library, and lastly Medical Research Council (MRC) library indicated that over $80 \%$ of the institutions had business continuity plan in place during the lockdown period. This meant that these institutions were operational, though with restrictions.

\section{Literature Review}

The literature review section consists mainly of current sources. There is limited literature on this phenomenon, more especially during times of crisis. .

\subsection{Overview of curbside services}

Curbside pick-up services originated in the 19th century and were initially associated with rubbish removal in England and France (Burns, 2014). Before the 19th century, many households used to burn or bury waste underground. However, industrialization and modernization prompted the need for eco-friendly and sustainable waste management systems. During this time, workers were employed by municipalities to pick up rubbish along the streets of the city (Burns, 2014). Since then, the concept has been adopted by other sectors. It is reported that major cities in America are engaging in converting parking lots into curbside pick-up sites. The idea is to help struggling restaurants during COVID-19. This method assists customers in picking up their meals at a nearby parking lot after placing 
orders (Berkal, 2021). Parking lots for curbside pick-up services is an effective way to offer services while adhering to strict health protocols.

Historically, libraries have provided book delivery services to their users. This service is more popular amongst universities offering Open Distance e-Learning (ODeL). In 1980, it was reported that Ohio State and the University of California at Berkeley implemented this service to facilitate and enhance access to their print books to their university patrons (Association of Research Libraries, 1980). Interestingly, some academic libraries have implemented book delivery services mainly for academic staff to their respective offices within their institutions (Mitchell and $\mathrm{Yu}, 2008$ ). This is corroborated by the initiative implemented by the Florida State University (FSU) Libraries in 2007 to deliver books requested by academic staff and postdoctoral student through an online form to their departments (Schoonover et al., 2014). This is quite different from the curbside pick-up services, where patrons request and collect directly from the library. Remarkably, the CHELSA report on Covid-19 (2020) has also indicated this an added service provided by some university libraries in South Africa.

The COVID-19 pandemic has prompted a sharp rise in curbside pick-up services in libraries. While there is evidence that libraries have implemented curbside book pick-up services as a solution during COVID-19 (Peking University Library, 2020; NWU, 2020). No scientific studies have been conducted specifically highlighting the implementation of this service in South African libraries or the world at large. This service has recently gained momentum after the Covid-19 outbreak with the closure of libraries worldwide to curb the spread of the virus.

\subsection{Academic libraries and ERT}

Libraries worldwide have been continuing with service provision even during the closure of universities to support ERT. With the easing of the lockdown restrictions, academic libraries started operating with a skeleton staff and limited access to the library's facilities and print resources. Before the COVID-19 pandemic, academic libraries provided library instruction in the form of face to face training sessions. This arrangement was severely affected as lockdown regulations tightened. Karakaya (2020) defines ERT "as a temporary solution to an immediate problem". Though libraries prioritized the procurement of eBooks in support of ERT, titles only available in printed format had to be made available to the users, whilst also taking precautionary measures. With this pedagogical practice in learning institutions, libraries were compelled to enhance their information provision services while maintaining safety precautionary measures. 


\subsection{Information dissemination during a crisis}

Dissemination of print materials during Covid-19 had bottlenecks, especially considering how the virus spreads. Information organisations such as libraries, museums, and archives had to practice safe precautionary measures to minimise the spread of the virus. In collaboration with the Online Computer Library Center (OCLC), the Institute of Museum and Library Services in the United States set up REALM (Reopening Archives, Libraries, and Museums) with guidelines on material handling to curb the spread of the virus (IFLA, 2020). Different authors have attempted to study the various information delivery methods given the availability of different modes. For instance, Kim et al. (2020) studied how users perceived AI-generated content in different modalities. It was found that users can tell the difference between synthetic and human voices in audio. Also, humangenerated videos were more effective than AI-generated videos because of the technicalities involved in creating the videos.

In contrast, AI-generated articles are perceived to be of high quality. Imammura et al.,. (2019) investigated information delivery methods and their association with adult memory and cognition. It remains to be seen how users in South African libraries perceive different information delivery methods associated with computing, especially during the COVID-19 pandemic. Printed materials were delivered in digitized formats with the assistance of copiers and scanners linked to computerised systems. Artificial Intelligence (AI) is transforming a wide range of sectors. In journalism, AI is employed to generate automated news writing and distribution without human supervision (Crespo, 2018). Libraries have also not been spared the influence of AI. According to Omane and Nmecha (2020), "AI is one of the emerging trends and applications of computing in libraries." Examples of AI used in libraries include expert systems for reference services, shelf reading robots, and virtual reality tours. In South Africa, most university libraries have employed automated chats on their website as an alternative to human-mediated reference services. As already highlighted in the background of the study, digitised copies of printed books were delivered with the help of computerised library systems. Various university libraries implement curbside pick-up services; however, there is no scientific literature available on this phenomenon, especially during the Covid-19 pandemic. Libraries that implemented these services used emails, telephone, ask a librarian feature, online request

form, and the lending desk (Medawar \& Tabet, 2020; RAILS 2020; NWU, 2021. Interestingly, these modes of communication have been used by various libraries to reach out to their users than before (Mi et al., 2020; Rafiq et al., 2020)

\section{Methodology}

This is a quantitative study that employed infometrics for data collection. This methodological approach is associated with studying quantifiable aspects of information in any form (TagueSutcliffe, 1992). The study analysed websites of all the 26 South African Universities to identify the embeddedness of curbside/book pick-up services during covid-19 in alignment with the first objective of the study. An excel spreadsheet has been used to collect data divided into various headings such as the university, curbside/book pick-up availability, modes of request, pick-up and drop-off, and the comments section where the researcher could record interesting facts such as the 
duration of book quarantining information. Data was then analysed and represented in graphs and tables.

\section{Findings and discussions}

The findings of the infometrics data collected are discussed below:

\subsection{Availability of curbside pick-up services in South African university libraries}

Figure 1 reflects the availability of curbside pick-up services implemented by South African university libraries in alignment with objective one. Of 26 libraries, 19 (73\% of 26) libraries had not implemented these services to facilitate the circulation of print books during the lockdown period. In contrast, only a smaller proportion of libraries 7 (27\% of 26) utilised this service to reach out to their users beyond the library walls. This indicates that most South African university libraries still have a lot to do regarding reinventing the wheel as far as lending services are concerned. These findings are similar to those reported by CHELSA (2020), where only a few libraries indicated the implantation of this service in their respective institutions. Furthermore, Guo et al. (2020) conducted a study on Chinese academic libraries, only reported $12 \%$ of libraries that agreed to use this service during Covid-19. These results indicate the need for libraries to reinvent the wheel and strategically innovate their services and practices to meet the changing needs of users, not only during a crisis but for everyday information needs.

Figure 1: Curbside pick-up service availability $(n=26)$.

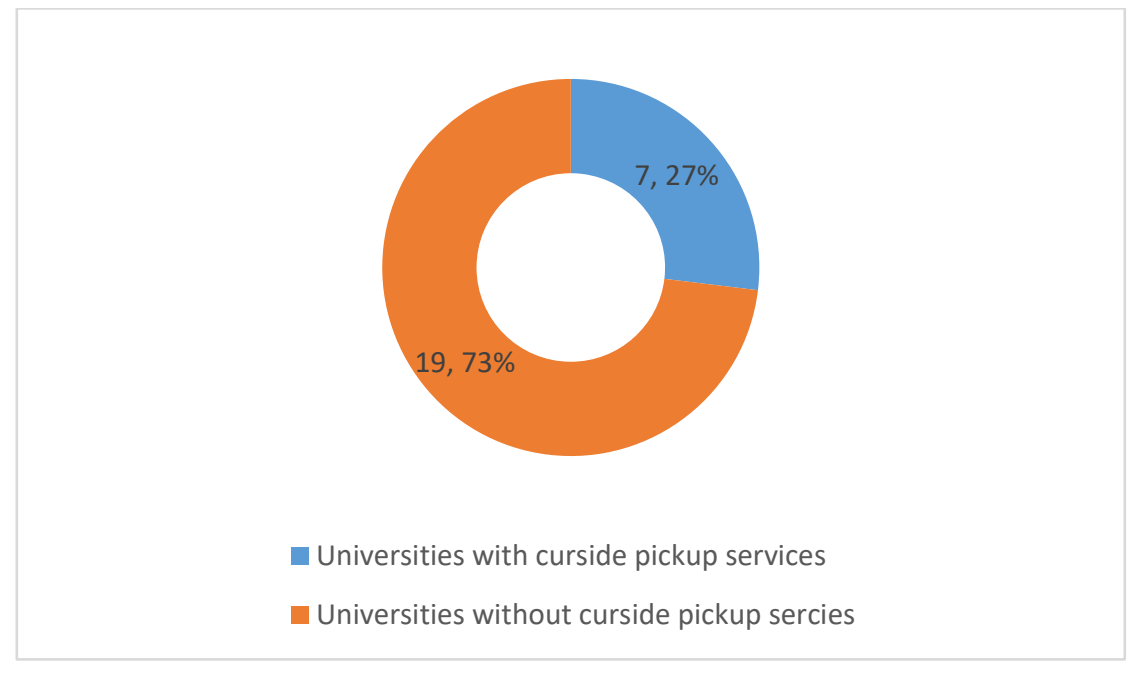

\subsection{Methods utilised for curbside book pick-up requests}

The study's second objective was to explore the book request method for facilitation of curbside book pick-ups. Figure 2 indicates the methods implemented by libraries in facilitating curbside/book pick-up requests. The findings show that most libraries used the telephonic method and email; out of 26 libraries, 4 (29\% of 26) reflected on their usage of these channels. Based on a study conducted on the university libraries response during the lockdown period, email has been identified as one of the main channels used (Rafiq, 2020). "Ask a Librarian" and the "Online Request Form" have been used equivalently ( 2 of 14\%). From the data gathered, the findings 
indicate that only a few libraries were using the lending desk and the Online library record ( 1 of $7 \%$ ). This might be because data was collected during the hard lockdown period, where access to libraries was limited. The literature reports on using these methods by most libraries in reaching and communicating with their users during the pandemic (CHELSA, 2020; Mi et al., 2020). The further indicate that some channels are more prioritised by some libraries than others. It can also be argued that libraries which are not utilizing certain channels might be aware of their user preferences and accessibility aspects. Platforms that are frequently used and easily accessible, such as email and telephone, have proven to be more popular.

\section{Figure 2: Book request methods $(n=26)$}

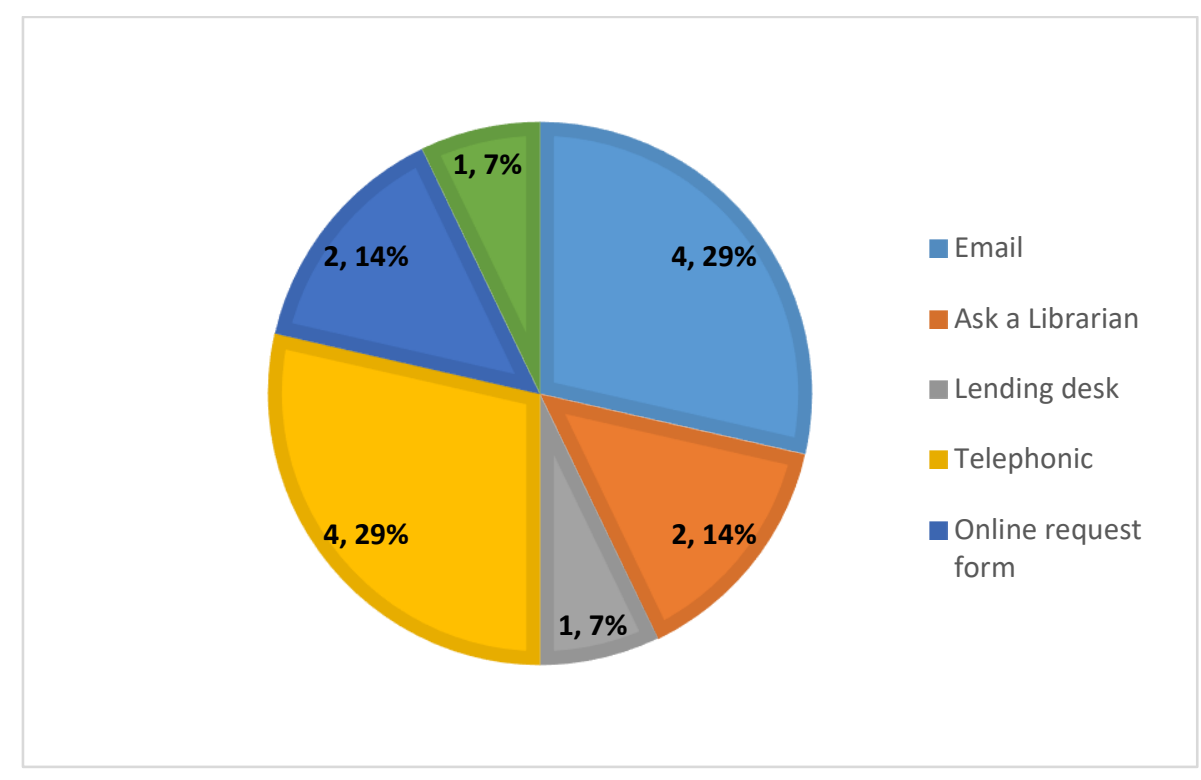

\section{Conclusion and recommendations}

The study aimed to investigate the implementation of curbside pick-up services by South African university libraries. It is therefore concluded that only a few South African libraries have implemented these services. Though ICT's have reinvented the library and information services field, some of the traditional services and resources such as print resources will remain. The study recommends that libraries stay abreast of changes in their field of expertise to meet the demands of their users. Library leaders and management need to strategise and invest in digitising their print collections to enhance accessibility and preservation. The publishing industry should also look into enhancing the production of books in various formats to enhance accessibility.

In addition to this, the study further highlights the importance of print collections in libraries. Collection development and circulation policies in libraries should provide guidelines and have contingency plans on maximising the access of collections amidst crisis. As this study was only limited to identifying South African University Libraries that have implemented curbside pick-up services, further research can be conducted on the perceptions of both library professionals and 
users on curbside pick-up services to ascertain challenges, benefits, and effectiveness of the service to shed light on this phenomenon.

\section{References}

Association of Research Libraries (ARL). 1982. Document Delivery Systems in ARL Libraries. Systems and Procedures Exchange Center. https://cutt.ly/Fb4D6XG Retrieved April 19, 2021.

Berkal, J. 2021. Curbside Competition. https://planning.org/planning/2020/oct/intersectionsparking/. Retrieved January 25, 2021.

Braun, L.W and Subramaniam, M. 2020. Curbside Pick-up Is Not The Answer: Libraries must do more to rework existing services. College Park: University of Maryland.

Burns, J. 2014. A Brief History of Curbside Collection. Rubbish Removals London. https://rubbishremovalslondon.com/a-brief-history-of-curbside-collection/. Retrieved January 252021

Campbell, A., Dumond, J., and Fink, P. 2020. Virtual (ly) Overnight: Providing Resources and Services in the era of COVID-19. Qualitative and Quantitative Methods in Libraries, 5566.

Committee of Higher Education Libraries of South Africa (CHELSA). 2021. Report on Covid-19 survey. https://chelsa.ac.za/wp-content/uploads/2020/08/covid19survey.pdf (accessed January 172021

Crespo, M. 2018. How artificial intelligence is transforming journalism. https://www.equaltimes.org/how-artificial-intelligence-is?lang=en\#.YA6H8GgzbIU. Retrieved January 25, 2020.

Gibson, A.N., Chancellor, R.L., Cooke, N.A., Dahlen, S.P., Patin, B. and Shorish, Y.L. 2020. "Struggling to breathe: COVID-19, protest and the LIS response", Equality, Diversity and Inclusion, Vol. ahead-of-print No. ahead-of-print. https://doi.org/10.1108/EDI-07-2020$\underline{0178}$

Guo, Y., Yang, Z., Yang, Z., Liu, Y. Q., Bielefield, A., \& Tharp, G. 2020. The provision of patron services in Chinese academic libraries responding to the COVID-19 pandemic. Library Hi Tech. Vol. ahead-of-print No. ahead-of-print. https://doi.org/10.1108/LHT-04-2020-0098

Harris, E.A. 2020. Libraries Strive to Stay 'Community Living Rooms' as They Reopen, The New York Times, New York.

IFLA (International Federation of Library Associations and Institutions). 2020. Key resources for Libraries in responding to the Coronavirus Pandemic. Retrieved from: https://www.ifla.org/covid-19-and-libraries\#safe 
Imamura, Y., Murakami, Y., Kimura, Y., Maeda, O., Tsujii, M., \& Konishi, K. 2019. Information Delivery Methods and their Association with Older Adults Memory and Comprehension. $J$ Aging Sci, 7, 207.

Karakaya, K. 2020. 'Design considerations in emergency remote teaching during the COVID=19 pandemic: a human-centered approach'. Educational Technology Research Technology Research and Development. https://doi.org/10.1007/s11423-020-09884-0. Retrieved 15 April 2021.

Kaiper-Marquez, A., Wolfe, E., Clymer, C., Lee, J., McLean, E. G., Prins, E., \& Stickel, T. 2020. On the fly: Adapting quickly to emergency remote instruction in a family literacy programme. International Review of Education, 1-23.

Kim, J., Shin, S., Bae, K., Oh, S., Park, E., \& del Pobil, A. P. 2020. Can AI be a content generator? Effects of content generators and information delivery methods on the psychology of content consumers. Telematics and Informatics, 55, 101452.

Lex, T. 2020. 'Yakima Valley Libraries will offer curbside pick-up services soon, Yakima HeraldRepublic'.Yakima Herald, August $10 . \quad$ Available at: https://www.akimaherald.com/news/local/yakima-valley-libraries-will-offer-curbsidepickup-services-soon/article_4fa3c5f8-529c-5b4b-a661-27a59dd6296a.html. Retrieved J 20 January 2021.

Lex, T. 2020. 'Grandview library to offer curbside pick-up services'. Yakima Herald-Republic, Available at: https://www.yakimaherald.com/news/local/grandview-library-to-offercurbside-pickup-services/article b51b7ef3-02a6-5823-8064-225912ca0d64.html.

Retrieved 20 January 2021.

Ma, L. F. 2020. Academic Library Services during COVID-19: The Experience of CUHK Library. International Information \& Library Review, 1-4.

Medawar, K., \& Tabet, M. 2021. Library collections and services during Covid-19: Qatar National Library experience. Alexandria, 0955749020986377.

Mi, M., Zhang, Y., Wu, L., \& Wu, W. (2020). Four health science librarians' experiences: How they responded to the COVID-19 pandemic crisis. College \& Research Libraries News, 81(7), 330-334. https://doi.org/ 10.5860/crln.81.7.330

Mitchell, E., \& Yu, C. 2008. Bringing delivery into the fold: a discussion of cross-departmental document delivery service implementation in academic libraries. Journal of access services, 5(1-2), 331-342.

North-West University (NWU). 2021. Covid-19 protocol. https://library.nwu.ac.za/sites/library.nwu.ac.za/files/files/documents/LIS-COVID-19Protocol_Jan-2021.pdf Retrieved 17 february 2021.

Omane, I.M \& Alex-Nmecha, J.C. 2020. Artificial Intelligence in Libraries. In: Managing and adapting Library Information Services for Future Users. Hershey: IGI Global. 
Peking University Library 2020. Fighting COVID-19 at home, free multimedia resources and new experience

multimedia resources. https://www.lib.pku.edu.cn/portal/cn/news/0000002117. Retrieved 15 April 2021.

Phalad, R. 2020. Summary of DALRO mandate regarding copyright during COVID-19. Legal Services: $\quad$ University of Kwazulu-Natal. http://legalservices.ukzn.ac.za/Libraries/General_Docs/SUMMARY_OF_DALRO_MAN DATE_REGARDING_COPYRIGHT_DURING_COVID-19.sflb.ashx. Retrieved 2 February 2021.

Publishers Association of South Africa. 2021. Industry news: COVID-19. Available at: https://www.publishsa.co.za/industry-news/covid-19. Retrieved 02 February 2021.

Rafiq, M., Batool, S. H., Ali, A. F., \& Ullah, M. (2021). University libraries response to COVID19 pandemic: A developing country perspective. The Journal of Academic Librarianship, 47(1), 102280.

RAILS. 2020. RAILS Guidelines for Libraries Considering Curbside Service and/or Phased Reopening. https://www.railslibraries.info/sites/default/files/Curbside\%20Delivery\%20and\%20Reop ening\%20-\%20May.pdf Retrieved 13 April 2021.

Rush, J. E. (1985). Review of" Document Delivery in the United States" by the Council of Library Resources (Book Review). Journal of the American Society for Information Science, 36(1), 57.

Smith Farrell, M. 2020. University Libraries Reopening Plan July 2020. https://ideaexchange.uakron.edu/cgi/viewcontent.cgi?article=1031\&context=libresearch ideas Retrieved 02 March 2021.

Schoonover, D., Siriwardena, M., \& Jones, R. 2013. Library express delivery service: The evolution of a campus delivery service at Florida State University. Journal of Interlibrary Loan, Document Delivery \& Electronic Reserve, 23(4-5), 201-212.

Tague-Sutcliffe, J. 1992. An introduction to informetrics. Information processing \& management, 28(1), 1-3.

Tammaro, A. M. (2020). COVID 19 and Libraries in Italy. International Information \& Library Review, 52(3), 216-220.

Zhang, T. 2020. Learning from the emergency remote teaching-learning in China when primary and secondary schools were disrupted by COVID-19 pandemic. Research Square. https://digitalcommons.cedarville.edu/cgi/viewcontent.cgi?article=1100\&context=educati on_publications Retrieved 20 February 2020. 
